\title{
Urea breath test for the detection of Helicobacter pylori using a stable isotope $\left({ }^{13} \mathrm{C}\right)$
}

\author{
Teste respiratório com isótopo estável (13C-uréia) para detecção do Helicobacter pylori
}

Ana Paula Werneck de Castro", 2; Ana Thereza Britto Gomes", 4; Gilberto João Padovan";

\section{key words \\ Helicobacter pylori \\ Urea breath test (UBT) \\ Urea labeled with radioactive \\ carbon $\left({ }^{14} \mathrm{C}\right)$}

Stable carbon $\left({ }^{(B C}\right)$

\author{
Ana Paula Werneck de Castro "; Ana Thereza Britto Gomes
Ricardo Brandt de Oliveira ${ }^{4}$; Julio Sérgio Marchini ${ }^{1}$
} Aceito para publicação em 07/08/03 Publicado em 20/04/04

\section{abstract}

Helicobacter pylori is found in the stomach of most patients with duodenal ulcer. Techniques for its diagnosis include histopathology, urease test and urea breath test (UBT) using urea labeled with radioactive $\left({ }^{14} \mathrm{C}\right)$ or stable carbon $\left({ }^{13} \mathrm{C}\right)$. The objectives of the present study were: 1$)$ to carry out UBT for the diagnosis of $H$. pylori using a stable isotope; 2 ) to compare the results with those obtained by the urease test, histology (considered to be the gold standard), and ${ }^{14} \mathrm{C}$ UBT. Fifty-four patients ( 25 women) aged 30 to 55 years were studied. The UBT showed $90 \%$ sensitivity and specificity (Kappa value ranging from 0.77 to 1.03 ). Detection levels at $30 \mathrm{~min}$ below $4.82 \delta \%$ were considered to be negative. Values between 4.82 and $14.968 \%$ were considered to be doubtful, with repetition of the test being recommended in these cases, while levels above this value were considered to be positive. The ${ }^{13} \mathrm{C}$ UBT was found to be practical, adequate, easy to carry out and harmless, thus being recommended as a diagnostic procedure for adults and children with suspected H. pylori infection, irrespective of sex or pathophysiological condition.

resumo

$\mathrm{O}$ H. pylori está presente no estômago da maioria dos pacientes portadores de úlcera duodenal. Para seu diagnóstico são utilizados: técnicas de histopatologia, o teste da urease e testes respiratórios (UBT) com uréia marcada com o isótopo radioativo $\left({ }^{14} \mathrm{C}\right)$ ou do estável $\left({ }^{13} \mathrm{C}\right)$. Este trabalho teve por objetivos: 1) realizar o UBT como procedimento diagnóstico da presença de $\mathrm{H}$. pylori utilizando isótopo estável; 2) comparar os resultados com os obtidos por meio da urease, histologia (considerados padrão-ouro) e UBT com ${ }^{14} \mathrm{C}$-uréia. Foram avaliados 54 pacientes com idades entre 30 e 55 anos, sendo 25 mulheres. O UBT apresentou sensibilidade e especificidade $90 \%$ (Kappa entre 0,77 e 1,03). Níveis de detecção, aos 30 minutos, menores que 4,828\%o foram considerados negativos. Entre 4,82 e 14,968\%o, duvidosos, recomendando repetir o teste, e acima deste valor, positivos. Neste estudo, o UBT com ${ }^{13} \mathrm{C}$-uréia foi prático, adequado, de fácil execução e inócuo, recomendando este procedimento diagnóstico na suspeita da presença do $\mathrm{H}$. pylori em adultos e crianças, independente do sexo ou condição fisiopatológica. unitermos Helicobacter pylori Testes respiratórios Uréia marcada com "C Carbono estável ("BC)

\footnotetext{
1. Division of Nutrology, Laboratory of Mass Spectrometry.

2. Craduate and scientific initiation student; Fapesp fellow.

3. Postgraduate student.

4. Division of Castroenterology.

This work was developed at the Department of Internal Medicine of Faculdade de Medicina de Ribeirão Preto of Universidade de São Paulo.
} 


\section{Introduction}

Helicobacter pylori is a Gram-negative spiral bacillus. Direct or indirect evidence of its presence can be found in $60 \%$ to $70 \%$ of patients with duodenal ulcer ${ }^{(1)}$. H. pylori is identified by histological examination, culture methods, determination of endonuclease and urease activity, serology based on the detection of specific serum antibodies (indirect immunofluorescence or immunoenzymatic assay), and by the urea breath test $(\mathrm{UBT})^{(2)}$.

The UBT is carried out using urea labeled with ${ }^{13} \mathrm{C}$ or ${ }^{14} \mathrm{C}$. If $\mathrm{H}$. pylori is present, bacterial urease hydrolyzes urea producing labeled $\mathrm{CO}_{2}$, which is eliminated by expiration ${ }^{(3)}$. The test is positive only if the bacterium is present, thus representing an advantage over tests for specific antibodies which might be detected in serum even when the bacterium has been eradicated ${ }^{(2)}$. The fundamental difference between the use of ${ }^{14} \mathrm{C}$ and ${ }^{13} \mathrm{C}$ is the fact that ${ }^{13} \mathrm{C}$ is a stable marker that does not emit irradiation, being harmless to humans, and can therefore be used in children and pregnant women. In addition, this isotope does not degrade over time and the test can thus be repeated as often as necessary ${ }^{(3)}$.

The objectives of the present study were: 1 ) to carry out for the first time at the university hospital of Faculdade de Medicina de Ribeirão Preto (HCFMRP) a UBT for the diagnosis of $\mathrm{H}$. pylori using ${ }^{13} \mathrm{C}$-urea; and 2) to determine its efficacy compared to histopathological analysis, the urease test (considered to be the gold standard), and the ${ }^{14} \mathrm{C}$ UBT.

\section{Material and method}

Patients attending the Gastroenterology Outpatient Clinic, HCFMRP, due to indication for esophagogastroduodenoscopy (Olympus GIF-100/GIF130 and Pentax EG 2901) were selected for the study. The procedures were performed in the morning after an overnight's fast. The combined results of the histopathological exam and of the urease test were considered to be the gold standard. The UBT was carried out within ten days after endoscopy and before the use of any medication. A subgroup of patients considered to be positive by the gold standard was treated with a triple or quadruple regimen in order to eradicate $H$. pylori, and the UBT was then repeated. The present protocol did not interfere at any time with the medical procedures to which the patients were submitted ${ }^{(4)}$.

\section{Laboratory tests}

Fragments of the distal antrum and gastric body, when indicated, were removed during endoscopic examination for histopathological analysis and the urease test. Then, the ${ }^{14} \mathrm{C}$ UBT $(5 \mu \mathrm{Ci})$ was carried out. These tests are routinely employed at HCFMRP(4).

\section{${ }^{13}$ C UBT}

After fasting, a basal expired air sample was collected into a collector bag (Quintron ${ }^{\circledast}$, Milwaukee, WI, USA) for the determination of basal ${ }^{13} \mathrm{CO}_{2}$. Orange juice $(200 \mathrm{~mL})$ containing $75 \mathrm{mg} 99 \%{ }^{13} \mathrm{C}$-urea (Masstrace, MA, USA) was then offered and expired air samples were collected at 15,30 and $45 \mathrm{~min}$. The excess ${ }^{13} \mathrm{C} /{ }^{12} \mathrm{C}$ ratio compared to basal levels, expressed as $\delta \% 0{ }^{13} \mathrm{CO}_{2}$, was determined with a mass spectrometer (Europa Scientific 20-20, Crewe, $\mathrm{UK})^{(5)}$.

\section{Statistical analysis}

Sensitivity, specificity, accuracy and kappa statistics were calculated for the UBT and compared to the gold standard. A confidence interval lower than 95 and $99.5 \%$ was calculated for positive results, and a confidence interval higher than 95 and $99.5 \%$ was calculated for negative results.

\section{Results and discussion}

Fifty-four patients ( 25 women and 29 men) ranging in age from 30 to 55 years were studied. A subgroup of ten positive patients were treated for $H$. pylori infection and then again submitted to the UBT.

Table 1 shows a comparison between the results obtained with the gold standard, the ${ }^{14} \mathrm{C}$ UBT and the ${ }^{13} \mathrm{C}$ UBT for expelled air samples obtained at 30 minutes. The sensitivity and specificity results are shown in Table 2. The $\delta \%$ values and confidence intervals are listed in Table 3. The ${ }^{13} \mathrm{C}$ and ${ }^{14} \mathrm{C}$ UBT results showed $100 \%$ agreement for both patients in whom the test was carried out only once and patients who were again submitted to the test after treatment.

The ${ }^{13} \mathrm{C}$ UBT was found to be practical and provided results similar to those of the ${ }^{14} \mathrm{C} U B T^{(4)}$. When compared to the gold standard, the ${ }^{13} \mathrm{C}$ UBT showed one false-positive and two false-negative results, leading to sensitivity, specificity and accuracy higher than $90 \%$. Kappa statistics showed very good agreement between the observed and the expected result. 
Results of the different tests used for the detection of Helicobacter pylori compared to those

Table 1 obtained with the ${ }^{13} \mathrm{C}$-urea breath test (UBT) at $30 \mathrm{~min}$

\begin{tabular}{|c|c|c|c|}
\hline & & \multicolumn{2}{|c|}{${ }^{13} \mathrm{C}$ UBT } \\
\hline & & Positive & Negative \\
\hline \multirow[t]{2}{*}{ Gold standard* } & Positive & 22 & 2 \\
\hline & Negative & 1 & 17 \\
\hline \multirow[t]{2}{*}{${ }^{14} \mathrm{C}$ UBT } & Positive & 18 & 0 \\
\hline & Negative & 0 & 22 \\
\hline
\end{tabular}

*Combined results of histopathological examination and the urease test.

Better agreement between the ${ }^{13} \mathrm{C}$ UBT and the gold standard was observed for samples collected 30 minutes after ${ }^{13} \mathrm{C}$ administration than for those collected at 15 and 45 minutes. Thus, in the present study, the best time for collection of the expiratory sample was 30 minutes, as also observed in other investigations, since the $\delta \%$ value might increase or remain stable thereafter. Samples collected at 15 minutes presented a larger number of false-positive results. $\delta \%$ values below 4.82 , which were defined as the maximum confidence limit for negative values, can definitively be considered to be negative, while the lower limit for positive tests was $14.96 \delta \%$. Test results of about $5-14 \delta \%$ were considered to be doubtful, and in these cases we recommend repetition of the test or, in the presence of prominent clinical signs, the institution of specific treatment.

The method of choice for the primary diagnosis of a specific gastroduodenal disease is endoscopy, since lesions can be visualized and biopsies collected. The UBT presents advantages in certain situations in which it is only necessary to detect the presence of $H$. pylori, because the test is well tolerated, does not present any risks, is relatively inexpensive, and does not require an experienced operator. The UBT can also be used during patient follow-up.
Treatment might eliminate $H$. pylori from the gastric antrum but small numbers of the bacterium may persist in the body and fundus. In this case, the UBT permits global detection of $H$. pylori in the stomach, in contrast to focal studies carried out on biopsy samples which employ histological and culture methods and the urease test ${ }^{(5)}$.

Determination of the efficacy of treatment and, therefore, of the eradication of $H$. pylori should take into account that the use of antibiotics, bismuth-containing medications and proton-pump inhibitors may reduce the number of bacteria below levels detectable by any existing method, with even a single dose of bismuth-containing medication being sufficient to give a false negative result. To avoid this problem, it is recommended to wait at least four weeks after the end of treatment to verify the eradication of $H$. pylori(7). Thus, the proposed criterion for the confirmation of eradication of the bacterium is two negative breath tests carried out one month or more after the end of treatment.

Administration of ${ }^{13} \mathrm{C}$-labeled urea in the absence of a test food leads to such a rapid gastric emptying that the time is not sufficient for the substrate to react with the $H$. pylori urease. Several types of food have been tested, but the best results were obtained with

Sensitivity and specificity of the ${ }^{13} \mathrm{C}$-urea breath test for the detection of Helicobacter pylori

Table 2 at $30 \mathrm{~min}$ (75mg ${ }^{13} \mathrm{C}$-urea, $99 \%$ enriched)

\begin{tabular}{lccc} 
& $\%$ mean & 95\% lower limit & $95 \%$ upper limit \\
\cline { 2 - 3 } Sensitivity $^{\S}$ & 95.7 & 87.3 & 104 \\
Specificity $^{\ddagger}$ & 94.4 & 83.9 & 105 \\
Accuracy $^{\dagger}$ & 95.1 & 88.5 & 101.7 \\
Kappa statistics* $^{*}$ & 0.9 & 0.77 & 1.03 \\
\hline
\end{tabular}

$\S$ Capacity of the test to detect a positive sample among all truly positive samples, i.e., all individuals who are truly infected with Helicobacter pylori; $\ddagger$ capacity of the test to distinguish a negative result when it is truly negative, i.e., all individuals who are not infected with Helicobacter pylori; faccuracy of an operation or a table, i.e., the proximity between an experimentally obtained value and a true value; ${ }^{*}$ corrected degree of agreement between the ${ }^{13} \mathrm{C}$ UBT and the gold standard. Agreement values $<0.2$, poor; $0.2-0.4$, weak; 0.41-0.6, moderate; 0.61-0.8, good; >0.8, very good. 


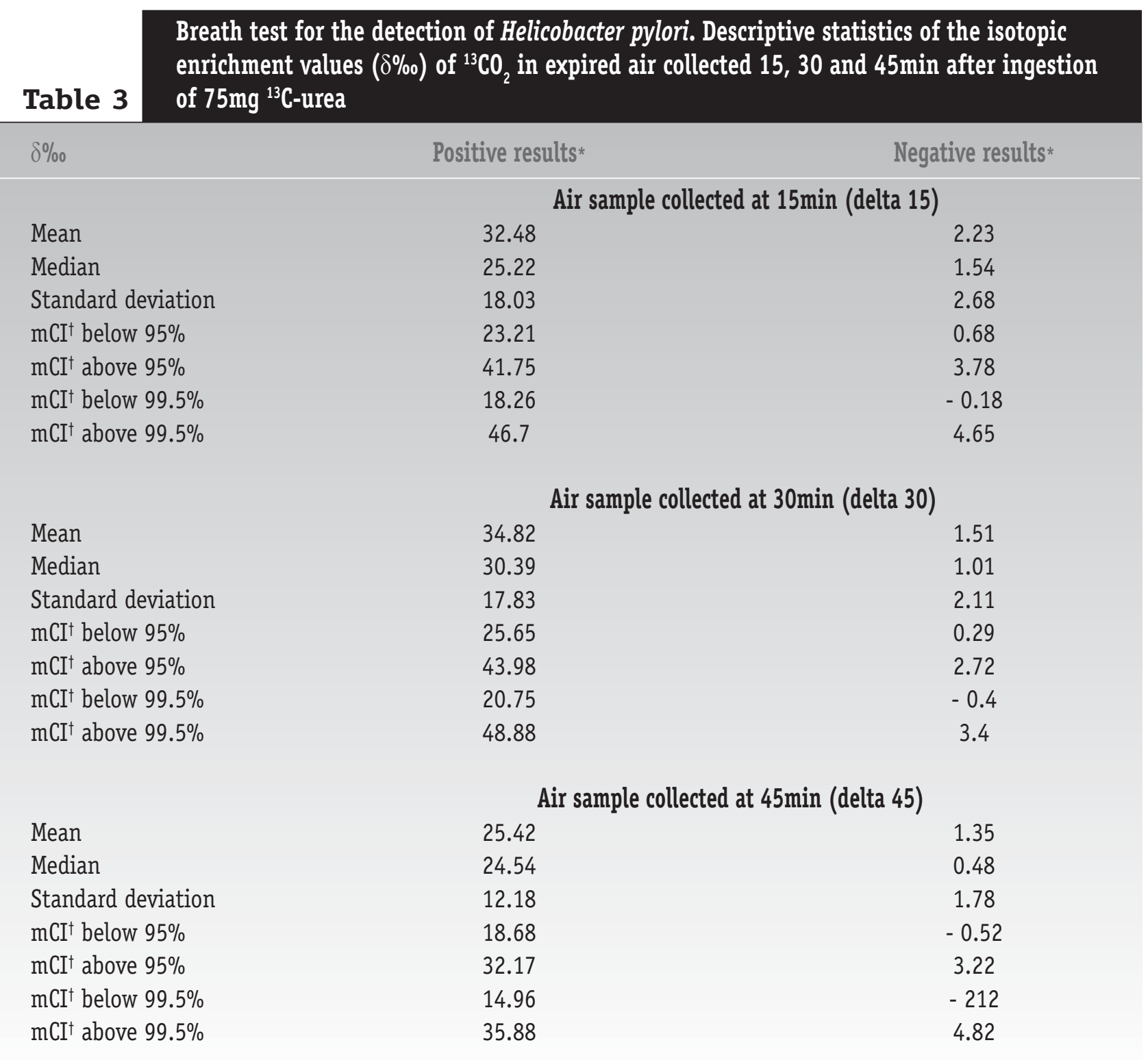

${ }^{*} \% \%$ values at 30min were collected according to the Current European Concepts in the Management of Helicobacter pylori Infection: The Maastricht Consensus Report ${ }^{(5)}$; tmean confidence interval.

the administration of citric acid or $200 \mathrm{~mL}$ orange juice ${ }^{(3,8,9)}$. The ${ }^{13} \mathrm{C}$ UBT is harmless and simple to apply, while the ${ }^{14} \mathrm{C}$-urea test is potentially harmful to humans and animals. ${ }^{14} \mathrm{C}$ emits $\mathrm{B}$-radiation and has a half-life of 5.730 years. Although B-radiation is considered to exert few damaging effects and the dose used $(5 \mu \mathrm{Ci})$ is at least 400 times lower than that causing skin erythema, the isotope can spread several meters in the air and penetrate skin or mucosa to deep layers, damaging germinative regions, thus leading to its possible accumulation in the organism of both patients and the medical team.
The present results show that the UBT was positive at 30 minutes for values higher than $14.968 \%$, with a confidence interval below $99.5 \%$, while values below $4.82 \delta \%$ o were considered to be negative. Results within this interval were considered to be doubtful and the test should be repeated in these cases.

\section{Acknowledgments}

We thank the support by Fapesp and HCRP/USP. 


\section{References}

I. ATHERTON, J. C. et al. Effect of test meal on the intragastric distribution of urea in the ${ }^{13} \mathrm{C}$-urea breath test for Helicobacter pylori. Gut, v. 36, p. 337-40, 1995.

2. ATHERTON, J. C.; SPILLER, R.C. The urea breath test for Helicobacter pylori. Gut, v. 35, p. 723-5, 1994.

3. CUTLER, A. F. et al. Accuracy of invasive and noninvasive tests to diagnose Helicobacter pylori infection. Gastroenterology, v. 109, p. |36-41, 1995.

4. DOMÍNGUEZ-MUÑOZ, J. E. et al. A citric acid solution is an optimal test meal in the ${ }^{13} \mathrm{C}$-urea breath test for diagnosis of Helicobacter pylori infections. Gut, v. 40, p. 459-62, 1997.

5. EGGERS, R. H. et al. A methodological analysis of the ${ }^{13} \mathrm{C}$-urea breath test for detection of Helicobacter pylori infections: high sensitivity and specificity within 30 minutes using $75 \mathrm{mg}$ of ${ }^{13}$ C-urea. Eur J Gastroenterol Hepatol, v. 2, p. 437-44, 1990.

6. GOMES, A. T. B. et al. Accuracy of the ${ }^{14} \mathrm{C}$-urea breath test for the diagnosis of Helicobacter pylori. São Paulo Med J, v. 120 , p. 68-7I, 2002.

7. MALFERTHEINER, P. et al. Current European concepts in the management of Helicobacter pylori infection: the Maastricht Consensus Report. The European Helicobacter pylori Study Group (EHPSG). Gut, v. 4I, p. 8-13, 1997.

8. MOSS, S. F. et al. Helicobacter pylori: more light, less heat. Am J Gastroenterology, v. 93, p. 306-10, 1998.

9. WARREN, J. R.; MARSHALL, B. J. Unidentified curved bacilli in gastric epithelium in active chronic gastritis. Lancet, v. I, p. 1273-5, 1983.

\section{Mailing address}

Julio Sérgio Marchini

Divisão de Nutrologia - FMRP/USP

Av. Bandeirantes 3.900

CEP 14049-900 - Ribeirão Preto-SP

Phone: (16) 602-3375/3187

e-mail: jsmarchini@fmrp.usp.br 